\title{
Erratum: Melough, M.M.; et al. Dietary Sources of Melamine Exposure among US Children and Adults in the National Health and Nutrition Examination Survey 2003-2004. Nutrients $2020,12,3844$
}

\author{
Melissa M. Melough ${ }^{1, * \mathbb{D}}$, Deborah Foster ${ }^{2}$, Amanda M. Fretts ${ }^{2}$ and Sheela Sathyanarayana ${ }^{1,3}$ \\ 1 Department of Child Health, Behavior, and Development, Seattle Children's Research Institute, \\ Seattle, WA 98101, USA; sheela.sathyanarayana@seattlechildrens.org \\ 2 Department of Epidemiology, School of Public Health, University of Washington, Seattle, WA 98195, USA; \\ dfoster4@uw.edu (D.F.); amfretts@uw.edu (A.M.F.) \\ 3 Department of Pediatrics, University of Washington, Seattle, WA 98105, USA \\ * Correspondence: melissa.melough@seattlechildrens.org
}

Citation: Melough, M.M.; Foster, D.; Fretts, A.M.; Sathyanarayana, S. Erratum: Melough, M.M.; et al. Dietary Sources of Melamine Exposure among US Children and Adults in the National Health and Nutrition Examination Survey 2003-2004. Nutrients 2020, 12, 3844. Nutrients 2021, 13, 958. https:// doi.org/10.3390/nu13030958

Received: 8 March 2021

Accepted: 10 March 2021

Published: 16 March 2021

Publisher's Note: MDPI stays neutral with regard to jurisdictional claims in published maps and institutional affiliations.

Copyright: (c) 2021 by the authors. Licensee MDPI, Basel, Switzerland. This article is an open access article distributed under the terms and conditions of the Creative Commons Attribution (CC BY) license (https:// creativecommons.org/licenses/by/ $4.0 /)$.
The authors have requested that the following changes be made to their paper [1].

The original authors wish to add Dr. Amanda M. Fretts as a coauthor to this paper, as she was mistakenly left off in the original published version. Contributions by Dr. Fretts included study conceptualization, supervision, and revision/editing of the manuscript. She approved the final manuscript for publication during August 2020. Unfortunately, it was not recognized by the authors until after publication that Dr. Fretts had been mistakenly left off of the author list.

We would like to apologize for any inconvenience caused to the authors and readers by this mistake. The published version will be updated on the article webpage, with reference to this notice.

Author Contributions: Conceptualization, A.M.F. and S.S.; formal analysis, M.M.M. and D.F.; data curation, M.M.M. and D.F.; writing-original draft preparation, M.M.M. and D.F.; writing-review and editing, M.M.M., D.F., A.M.F. and S.S.; supervision, A.M.F.; project administration, S.S. All authors have read and agreed to the published version of the manuscript.

Funding: This research was funded by the Health Resources and Services Administration of the US Department of Health and Human Services, grant number T76MC00011.

Conflicts of Interest: The authors declare no conflict of interest.

\section{Reference}

1. Melough, M.M.; Foster, D.; Sathyanarayana, S. Dietary Sources of Melamine Exposure among US Children and Adults in the National Health and Nutrition Examination Survey 2003-2004. Nutrients 2020, 12, 3844. [CrossRef] 